V. Shevchenko,

DrHab (Technical), Professor, ORCID 0000-0002-7290-811X, Institute of Geotechnical Mechanics named after N. Polyakov NAS Ukraine, Dnipro,

N. Osadcha, DrHab (Economics), ORCID 0000-0001-5066-2174, Institute of Industrial Economics of NAS of Ukraine, Dnipro,

O. Kolomiytsev, PhD (Psychology), ORCID 0000-0002-2711-9883

O. Kotko, $\mathrm{PhD}$ (Economics), ORCID 0000-0002-9244-3583

State Enterprise “Investment-Innovation Centre”, Dnipro

\title{
TENDENCIES AND PROSPECTS OF THE UKRAINIAN NUCLEAR INDUSTRY COMPLEX DEVELOPMENT
}

Under the conditions of transition to the 6th technological structure, helio- and nuclear energy become the leading sources of energy resources $[1 ; 2]$. In general, in Ukraine, about 1000 tons of uranium concentrate are produced per year in modern conditions, but real investments are needed not to increase production but to make it. The need to increase uranium production and its further conversion into nuclear fuel has been talked about without exception by the all Ukrainian governments. According to the view of some experts, our country ranks first in Europe by its reserves and is in the top ten in the world. By even the most modest of their estimates, raw materials will last for a hundred years [14].

2,5 thousand tons of uranium concentrate are required annually to support electricity production by operating NPPs. Ten years ago, an ambitious program "Nuclear Fuel of Ukraine" was adopted, with plans to increase uranium concentrate production up to 1880 tons per year, construction of a nuclear fuel plant and production of 270 tons of zirconium per year. But in fact it turned out ... as always. Therefore, modern Ukraine only produces natural uranium concentrate, which is actually a low value-added raw material and is further enriched for the production of uranium dioxide-enriched tablets from which fuel elements are formed. It should be noted that the required amount of uranium enriched in nuclear fuel is purchased by Ukraine only in the Russian Federation. Russia supplies uranium-235 dump after enrichment of at least $0.3 \%$. Similar developments are being made by the US at Westinghouse.

Analysis of recent researches and publications. The study of problems of atomic industrial complex development dedicated their works: A. Nosovsky [4], L. Litvinsky, O. Purtov [5] A. Maksimchuk [6] G. Mohon'ko, K. Tarasenko [7].

Despite the significant attention of scientists, the problem of conditions formation for innovative-oriented development of nuclear-industrial complex requires more study.

The main purpose of the study is to develop the sequence of conditions formation of innovation-oriented development of nuclear-industrial complex in Ukraine on the basis of strategic determinants.

Presentation of the basic material. The development of the economy and the increase in population is one of the reasons for the growth in energy demand in modern conditions. Over the past 20 years, the world population increased by 1.6 billion people, and the total real income of the population and enterprises - by $87 \%$. The consumption of primary energy has increased from 1900 in 22.5 times, and over the last 20 years the volume of world primary energy consumption grew by $45 \%$. Structure of primary energy consumption carriers in separate countries is defined with the natural resources and transport capacities availability, the nature of the internal needs. The increase in world primary energy demand is determined such country and regions as China, India, Brazil and the middle East. Although historically 
nuclear energy has risen from its programs to develop nuclear weapons, here, of course, reverse is possible.

Now Ukraine produces about 1,000 tons of uranium concentrate per year. The level of concentrate provision from the beginning of the Millennium has increased only from 32 to $40 \%$. The rest (up to 1500 tons) are annually purchased from Russian, European and Kazakh suppliers. Meanwhile, older fields are depleted and there is very little money to develop new ones. Besides the cost of our uranium by global standards is very high $-\$ 105$ per $\mathrm{kg}$, which is more than twice higher to the current world quotes. And, of course, around this area there are a bunch of shady semi-criminal schemes.

Geographically, almost all developed (and promising) deposits are concentrated in a small area (size of 80 to $20 \mathrm{~km}$ ) within Kirovohrad region. The only uranium producer in Ukraine - Eastern mining-processing combine (SkhidHZK) operates there. Its purpose and specialization is mining and processing of uranium ore. SkhidHZK consists of three mines: Inhul's'ka, Smolins'ka and Novokostyantynivs'ka which develop four deposits. Moreover, the Inhul's'ka mine runs two of them at the same time. Hydrometallurgical plant SkhidHZK in Zhovti Vody is engaged in the processing of ore into uranium oxide. Then it traditionally goes to the Russian Federation for the enrichment and fabrication of fuel assemblies (FA) in fact, fuel for Ukrainian nuclear power generating stations.

The management structure of the SkhidHZK is part of the state concern created in 2008 "Nuclear fuel" with tasks: creation of a plant for the production of nuclear fuel, the uranium and establish production of zirconium. From all three tasks in fact are performed only extraction of uranium ( $97 \%$ of turnover) and some release of hafnium (up to $12 \mathrm{t}$. per year).

There are two saved enterprises in Ukraine for extraction and processing of uranium, the existing technology of building electronic components and even a special measuring technique to determine the isotopic composition of nuclear materials. Moreover, reserves of uranium and zirconium in Ukraine, as mentioned above, one of the first in the world.

A unique feature of domestic production is that a considerable part of the ore is extracted directly under the regional centre - the city of Kropivnitsky (before Kirovohrad). On the outskirts of the city is located Inhul's'ka mine which has created an underground labyrinth in the depths of half a century (from $160 \mathrm{~m}$. till 650 $\mathrm{m}$,). There are only 5 vertical trunks, plus the two uranium deposits - Michurins'kyi ta Tsentral'nyi with an underground tunnel nearly $6 \mathrm{~km}$ long, passing under the river Ingul. There will be enough uranium reserves until 2030. And there is a large undeveloped Central (Zakhidne (Western) deposit nearby. However, the uranium deposits there go almost to the center of the city, which for obvious reasons does not cause great enthusiasm among its residents.
Smolins'ka mine, which is located $80 \mathrm{~km}$ to the west, has many more problems - it is going to be closed. Since the uranium content is higher, the mine has long been a key to mining and processing plant, giving up to $60 \%$ of raw materials. But more intensive testing of the Vatutins kyi deposit accelerated the depletion of available reserves. Latest commissioned seven years ago, an ore horizon $640 \mathrm{~m}$. only slowed the pace of decline. The plant capacity in recent years has decreased more than twice. Before the accident at the Fukushima Japanese nuclear power plant, during the period of high uranium prices in the world, the option of working out even deeper horizons of the Vatutins 'kyi deposit and exploration for exploration of a small neighboring southern deposit was considered. However, the fall in uranium prices made these plans unprofitable. Already in 2016, the Nuclear Fuel Concern has decided that it is inappropriate to continue the operation of the Smolin Mine. In the spring of 2017, there was also an official statement that the residual resource of the mine does not exceed 1.4 thousand tons of uranium, and it will be closed within 3-5 years. At the same time, it is more than a serious blow to the village Smoline, for which the mine is a city-forming enterprise. The village Smoline risks of being left with nothing, since there is no money for the new jobs creation either in the State Mining and Gas Company or in the states.

The main hope associated with the development of neighboring Novokostyantynivs'ka mine. And now the Director of the Smolins'ka mine at the same time controls them both. Previously it was assumed that part of the mine personnel will go to Novokostyantynivs'ka mine, which is in pilot operation (that is in fact still under development). But even if so, not everyone will be able to get a job.

The history of the decommissioning of mines in the town Zhovti Vody that were previously included in the SkhidHZK, also does not add optimism. They flooded, and one of them ("Nova") went under water, having iron ore reserves of almost a billion tons. Now SkhidHZK task is to maintain the existing volume of production at old fields at the level of 650-670 tons/year and commissioning of the startup complex with a capacity of 500550 tons/year at Novokostyantynivs'ka mine.

The newest mine is talked a lot and often. Total uranium reserves at operating mines - about 110 thousand tons, the lion's share -92 thousand tons $(84 \%)$ is exactly resources from Novokostyantynivs'ka. But, unfortunately, much less is being done.

In recent years, construction is funded only by the plant, and even then very little. Thus, in 2016, the total investment of the mining company (SkhidHZK) in support of existing mines, "and further development of the Novokostyantynivs'kyi deposit" was only $\$ 4.5$ million. At the same time, minimal valuation of the cost of commissioning a start-up complex of this mine with the output for production of 500 thousand tons of ore per year 
are at least ten times greater. The projected capacity 1500000 tonnes of uranium ore per year - will require about a quarter of a billion dollars. There is no such money in SkhidHZK. Now, mining is shallow underground, with a horizon of $240-300 \mathrm{~m}$. The main uranium lies deeper (up to $700 \mathrm{~m}$ ), but there is no money to reach it. On the surface of the mined rock mass is lifted by two very worn trunks. However, everything is not so bad. There is uranium there, and the volumes of its production at this mine have already exceeded the level of the Vatutins'kyi field. And even expensive uranium electricity is clearly cheaper than electricity from Ukrainian coal.

But some technologies for organizing a closed nuclear cycle in Ukraine are still lacking. Only the initial stage of uranium ore enrichment is possible at Ukrainian enterprises. It should be noted that investment is needed due to the lack of technology and production facilities for the construction of high and low power reactors. In Ukraine there is a complete (closed) nuclear fuel cycle. However, there are some of its key elements: the extraction, crushing, and enrichment of uranium ore to produce uranium oxide $\left(\mathrm{U}_{3} \mathrm{O}_{8}\right)$; the use of nuclear fuel (energy and research reactors); storage of spent nuclear fuel; transportation of fresh and spent fuel and radioactive waste, storage and disposal of radioactive waste. I.e, the modern nuclear-industrial complex of Ukraine includes: uranium ore production, production of nitrous oxide, production of zirconium concentrate for the production of shells (tubes) for fuel elements (TVELs) and operating NPPs [3].

The composition of the enterprises that are the part of the nuclear industry of Ukraine, which can be represented in the form (Table).

The main enterprises of the nuclear-industrial complex of Ukraine and the profile of their activity

\begin{tabular}{|l|l|}
\hline \multicolumn{1}{|c|}{ Name of Company } & \multicolumn{1}{c|}{ Profile } \\
\hline State concern "Nuclear fuel" & Uranium and zirconium production \\
\hline Members of the concern: & \\
\hline $\begin{array}{l}\text { SE "Eastern Mining and Processing Plant" } \\
\text { (SkhidHZK) }\end{array}$ & $\begin{array}{l}\text { Natural uranium production and production of its ox- } \\
\text { ide concentrate }\end{array}$ \\
\hline SE "Smoly" & $\begin{array}{l}\text { Production and marketing of ionized materials and } \\
\text { their provision in the full volume of uranium produc- } \\
\text { tion of Ukraine }\end{array}$ \\
\hline $\begin{array}{l}\text { State Enterprise "Ukrainian Research and Design In- } \\
\text { telligence Institute of Industrial Technology" }\end{array}$ & $\begin{array}{l}\text { Project and scientific support of facilities and produc- } \\
\text { tion of nuclear fuel cycle }\end{array}$ \\
\hline Other enterprises serving the leading structural units of nuclear power and the nuclear-industrial complex \\
\hline
\end{tabular}

Leading structural units of a nuclear (atomic) energy is a state enterprise "National nuclear energy generating company "Energoatom" and its separate divisions, and the nuclear-industrial complex - the state concern "Nuclear fuel", which is the SE "Eastern mining and processing plant", SE "Resin", SE "Ukrainian scientific research and design-prospecting Institute of industrial technology".

Directly the nuclear-industrial complex, which is the leading element of the nuclear energy complex of Ukraine can be considered a complex sector of the national economy that includes production of uranium, which forms the basis to meet the needs of nuclear power plants in natural uranium in the medium and long term; zirconium production, which includes the establishment of the production of zirconium, which is the main structural material for the fabrication of nuclear fuel, given its unique physical properties of the weak interaction with neutron flux in the reactor core; manufacture of ion-exchange materials and to ensure the full production of uranium of Ukraine; production of fuel assemblies and components as an integral part in the creation of our own nuclear-fuel cycle; scientific, project and informational support of carrying out research and experimental design works for the improvement of mining technologies, processing of uranium raw materials, ensuring radiation protection of personnel and population, conducting environmental impact assessment, technical re-equipment of research institutions and design organizations.

Such elements of the nuclear fuel cycle, like uranium conversion (the translation of the nitrous-oxide of uranium $\mathrm{U}_{3} \mathrm{O}_{8}$ in uranium hexafluoride UF6 gaseous compound, which is technologically necessary for further enrichment), isotopic enrichment of uranium and its re-conversion (conversion of enriched uranium hexafluoride to uranium oxide), manufacturing fuel pellets of uranium oxide, and fabricating finished fuel assembliestoday in Ukraine does not exist. The country does not have a complete nuclear fuel cycle (NFC) - there is no stages: obtaining uranium hexafluoride; enrichment, conversion and production of fuel tablets, obtaining pipe billets and rolled products; manufacture of components and fuel assemblies. In general, the available scientific potential and experimental base are insufficient for scientific and technical support nuclear cycle in Ukraine. Massive financial problems are a huge obstacle for the realization of such ambitions. After all, the actual funding for most of the existing nuclear cycle programs during the years of independence did not exceed 10 per- 
cent of the announced level. According to the IAEA, uranium reserves of Ukraine is about 199.5 thousand tons. In Ukraine are produced only natural uranium concentrate, in fact a low cost raw material, unsuitable for further enrichment and the production of uranium dioxide tablets. It does not allow Ukraine to fully utilize uranium isotopes 235 and 238. Until recently, the required amount of enriched uranium in nuclear fuel was only purchased in the Russian Federation.

Despite the fact that the contribution of the nuclearindustrial complex of Ukraine in the creation of gross domestic product is not significant, but its role is important in ensuring economic security and achieving energy independence. In accordance with the provisions of the sustainable development Strategy of Ukraine until 2030 and the energy strategy of Ukraine for the period up to 2035 the development of nuclear energy is one of the priorities of development of national economic system.

The process of controlling the development of nuclear-industrial complex is a difficult, multifaceted process. Make informed and appropriate management decisions is possible only under the condition that they are based on the results of the objective assessment, which enables to identify the type of development and determine its level, create a basis for identifying determinants of development. The world's leading companies enter into contracts for uranium enrichment under IAEA control with the receipt of a uranium dump -235 is $0.2 \%$ or less. This allows to obtain the isotope uranium-235 not $67 \%$, but $80 \%$ or more. Ukraine is working in an imperfect legal field. There is no effective state mechanism for regulating the development of the nuclear-industrial complex: it has no instruments or state programs. The following programs exist in Ukraine: State Target Economic Program "Nuclear Fuel of Ukraine", approved by the Cabinet of Ministers of Ukraine from September 23, 2009 No. 1004 for the period 2009-2013, which provides for an increase in the production of natural uranium concentrate; creation of nuclear fuel production, zirconium production, production of accessories; scientific, project and information support of nuclear fuel cycle facilities; The State Program "Nuclear Fuel of Ukraine" was adopted for the period 2009-2013; The Decree of the Cabinet of Ministers of Ukraine of November 9, 2016 No. 943-p approved the Concept of the State Target Economic Program for the Development of the Nuclear Industrial Complex for the Period up to 2020; The concept of the nuclear fuel production and its components organization in Ukraine is based on national resources of natural uranium and zirconium to reduce the dependence on foreign suppliers of nuclear fuel for nuclear power plants.

The next step after approval of the Concept is the development of the draft programme, but as for today, the draft program of the Cabinet of Ministers of Ukraine is not approved. Resolution of the Cabinet of Ministers of Ukraine of 30 September 2009 No. 1029 was approved the State target ecological programme to bring in a safe state of the uranium objects of the production of "Prydniprovs 'kyy chemical plant" Association.

The goal of the program is to eliminate negative environmental impacts of industrial Association "Prydniprovs 'kyy chemical plant", bringing the dangerous uranium objects which are on the balance of the state enterprise "Barrier" into an environmentally safe condition and providing protection of the environment and population from the harmful effects of ionizing radiation. The term of program implementation 2009-2014, ie the Program requires updating.

The decision of the Dnipropetrovsk regional Council from 21.10.2015 No. 680-34/VI approved of the Dnipropetrovsk regional complex program (strategy) of environmental security and mitigation of climate change for 2016-2025. On October, 21, 2015 Dnipropetrovsk Regional Council Decision approved Dnipropetrovsk Regional complex program (strategy) for environmental safety and the climate change prevention for 2016-2025 (decision № 680-34 / VI). This program is not paid enough attention to the issue of radioactive waste disposal although among the problems include significant man-made load on the environment of giant tailings and sludge collectors in the town Zhovti Vody and the state enterprise "Barrier" (Kam"yans'ke).

Despite the decline in commodity prices in the world. Energy security of the country is one of the national interests of the state.

In Ukraine, on June 21, 2018, Law No. 2469 -VIII "On National Security" was adopted.The Law defines the terms "public security - protection of state sovereignty, territorial integrity and democratic constitutional order and other vital national interests of actual and potential non-military threats", "threats to national security of Ukraine - the phenomenon, trends and factors that make it impossible or difficult or might prevent or hinder the realization of national interests and the preservation of national values of Ukraine, national security protection of state sovereignty, territorial integrity, democratic constitutional rights and other national interests against real and potential threats and national interests vital interests of the person, society and state, realization of which ensures the state sovereignty of Ukraine and its progressive democratic development, as well as safe living conditions and the well-being of its citizens". Therefore, on this basis, it is possible to generalize the system of interaction of subjects, objects and components of the influence of national interests. Scientific research and development of the nuclear-industrial complex for the modern developed country is an integral part of the realization and protection of the state national interests, as well as an element of state and national security. The concept of "interests in the development of the nuclearindustrial complex" is formed in the system of national interests. The definition of "interests in the development 
of the nuclear-industrial complex" should take into account the following factors: set of economic interests; a set of state energy security goals; set of existing external and internal threats.

The second problem with the production is the necessity of growth of uranium ore production in 2,53 times, to 2.6 million tons per year. One of the scientific methods of mining uranium, which it is advisable to use in Ukraine is in-situ leaching (ISL) of uranium on explored sandstone deposits. This method is used by Kazakhstan and Uzbekistan. In these countries, $100 \%$ of uranium is mined by ISL method. Ukraine needs to maintain and develop its nuclear energy potential, even in spite of the trend towards a policy of some states' abandonment of nuclear energy. Nuclear power is not just part of the energy industry. It is a reflection of a certain level of economic development, technology, education and even public relations. Nuclear power is an indicator that confirms the technological culture, it demonstrates membership relatively narrow range of countries, the level of development which allows safely and effectively use the latest achievements of engineering thought especially in the conditions of transition to the 6th technological order.

It should be noted that many countries have renounced nuclear energy. But these countries are not energetically isolated, and their energy market is a component and fully integrated part of the EU market, where nuclear generation is present. Among countries such as Germany, which shows a move away from nuclear power, but it is part of a common European energy market, together with France, where nuclear power is dominant. One notable example is the state of California, which decades ago made the decision to decommission nuclear power units located in its territory, but in 2019 has decided to extend their service life. This is against the background of the general rise and development of nuclear power and reactor technology in the United States. There is no doubt that Ukraine, together with Poland, should maintain and develop their own potential in nuclear energy and related industries. In order to preserve and develop Ukrainian nuclear power, it is necessary to fulfill a number of conditions and implement a set of measures.

Nowadays, electricity from Ukrainian nuclear power plants is generally the cheapest in the world. With the current rate of about 2 cents per kilowatt/hour, it is three to four times cheaper than in Europe and 1.5 times than Russian! However, such cheapness does not make it possible to accumulate resources not only for the development but also for the safe decommissioning of the NPP units, followed by bringing the sites where they are located, in a safe condition. To put it bluntly, there is a decline in the cost of renewal and the shifting of problems to future generations.

The most obvious (and sad) scenario: nuclear power plant will modify its resources (most likely, given the multiple extensions) and will be closed. For uranium miners, this means that by 2050 , the local uranium consumer will also dry up. But this is a distant problem today. Last year, according to the SE "Eastern Mining and Processing Plant" (SkhidHZK) report, "1240 tonnes of uranium concentrate was sold. Total revenue of $\$ 4.2$ billion was received and nearly $\$ 1$ billion was paid in taxes."

At the same time, it should not be excluded that part of the purchased on the domestic concentrate is also purchased on the foreign market. In fact, one of the shadow schemes, which slowly still came to court [14], was the purchase of a cheap Kazakh concentrate, followed by its sale to the state through the SkhidHZK, but, of course, at higher prices. According to the contract, the state-owned national atomic energy generating company "Energoatom", which operates the NPP in the period 2008-2018 purchases the extracted uranium concentrate (in the SE "Eastern Mining and Processing Plant" (SkhidHZK). And at the prices that ensure the profit of the latter, that is much higher than the current prices in the market.

In 2014-2015, one of the intermediary firms, Austrian Steuermann Investitions, bought 400 tonnes of concentrate in Kazakhstan at $\$ 95 / \mathrm{kg}$, then resold it to SkhidHZK, but at $\$ 129 / \mathrm{kg}$, and the mining and processing plant resold it; Energoatom; (who is obliged to buy uranium from it) at the same price. Under the 20142015 contracts, SkhidHZK had to purchase up to 1000 tonnes of uranium concentrate through the Austrian intermediary (approximately its annual output). Now all these schemes will be dismantled in the courts.

And SkhidHZK, meanwhile, has set "an overriding goal": reducing uranium cost from $\$ 105$ per kilogram in 2017 to $\$ 80$ during 2018-2019. By the way, the second figure, is also higher than world prices, which are expected to grow in 5-7 years. It is not very clear how everything will work out in practice. Uranium waste reserves have already been largely selected. There is no money for digging new horizons. However, it is possible to close down the Smolins 'ka mine. But there has already been one strike at the the SE "Eastern Mining and Processing Plant" (SkhidHZK). By the way, during the court cases, an interesting document was lit up against the strikers. The Ingul'ska mine was paid only at 1,000 UAH / $\mathrm{kg}$ (less than \$ 40).

Development, new technologies and horizons [13]. While operating existing power units, it is extremely important for Ukraine to monitor and directly participate in the development of new technologies and to implement them. Among the main directions are:

Firstly- modern technologies that allow to modernize, increase efficiency, replace already existing power units, including units of small capacity, increase their safety and extend their service life. It is advisable to put this on a domestic engineering base with the use of USA and Canada modern technologies. Such enter- 
prises in Ukraine are currently manufacturing separate components for fittings and equipment for nuclear reactors.

A certain group of experts associates the main hope for the increase of Ukrainian uranium production with the Chinese. For the last two years, Chinese delegations regularly visited Novokostyantynivs'ka mine and hydrometallurgical plant (where they want to participate in the construction of a sulfuric acid plant). In August 2017 at the request of the State Development Bank of China; SkhidHZK has ordered an audit of its financial statements for the past three years.

Incidentally, in 2006-2011, Novokostyantynivs'ka mine was already a separate legal entity - at that time it was expected that "Rosatom" would come to it as an investor; (with an expected investment of $\$ 500$ million). What is interesting is that "Rosatom"; could not find any money within his country. Today's expectations are more modest: local authorities say about \$ 160 million, Chinese themselves does not comment a process as well as its financial component. SkhidHZK is not a subject to privatization (still a strategic enterprise), but other indirect and relatively temporary forms are possible - rent, long-term concession, joint venture creation, pledge of products and others.

At the same time, there is already a Russian precedent-analogue. In the spring of 2018, the Chinese National Nuclear Corporation (CNNC) signed with "Rosatom" a contract to finance the renewal of the uranium mine in Transbaikalia. A joint venture will be set up in which China's representatives will receive $49 \%$ and the right to export half of the uranium produced (that's 600 tonnes / year). A similar option was offered to Ukraine. China has 38 operating nuclear reactors and plans to build another two dozen by 2025 . It is actively buying up uranium mining assets in Kazakhstan, Uzbekistan, Niger and even Canada. It is planned that in the future, China will produce one third of uranium domestically, one third - overseas at enterprises with Chinese involvement, the rest will buy the market. A large state reserve of uranium is also created. So, Beijing has an interest.

While the bidding process is ongoing with China, it is said in public that at Novokonstantinovska mine, the the SE "Eastern Mining and Processing Plant" (SkhidHZK) has been fruitfully cooperating with the Chinese Development Bank. As stated, "the Chinese side noted the considerable experience in the development of uranium deposits and emphasized the interest in the implementation of these projects". The Chinese are rather peculiar and tough partners, especially in this field. Beijing has plans to extract uranium at the expense of its investment. Last year China National Nuclear Corporation together with concern "Nuclear fuel" approved a plan of action for joint production of nuclear fuel for VVER-1000 reactors in Ukraine.

In general, the history of the nuclear fuel plant creation is interesting and may reappear. And not only with the Chinese, but also with ourselves. It seems that soon we will hear about Oleksander Dubov as a whole and about the resuscitation of the joint venture structural subdivision UkrTV, in particular. There are other supercritical domestic investors. Last year and beyond last year, the courts of five uranium ore deposits in the Mykolaiv and Dnipropetrovsk regions benefited the recently established Atomic Energy systems of Ukraine, LLC (AESU), which has received a permit for them; geological exploration and development. It concerns the Safonivs 'ka area, Mikhailivs 'ka and Sadova plots in the Mykolaiv region, as well as the Novogur'evs'ka plot and the Surs ka square in the Dnipropetrovsk region. NPP offered to grant them special permits for five years without auctions, because before that the firm rented complete property complexes in the contours of these fields. Uranium is going to be extracted by leaching (ie pumping it into an acid solution layer). It is interesting that at the end of the zero years all these deposits were on the list of the most promising, and Safonivs 'ke - with 3 thousand tons of reserves and the prospect of extracting 150-300 tons of uranium ore a year is still included in the Cabinet uranium concept [14].

The second area concerns new reactor technologies. The country's energy strategy indicates the need to identify the next generation of nuclear reactors we plan to operate. Ukraine has a unique opportunity to work with technology companies in the United States to gain leadership in the development of small module reactor technology. This is a new generation of reactor units up to $300 \mathrm{MW}$, with significantly higher efficiency and security. In addition to using new technologies for our own needs, we can become a regional engineering and technological hub with export technological potential and significant localization of production at domestic machine-building enterprises.

Fuel diversification and expansion of our own base is the third area of concern. Ukraine needs to maintain a policy of fuel diversification and reduce the risks of using fuel supplied by the Russian Federation. At the same time, the mineral and technological base available in Ukraine makes it possible to speak about the possibility and the need to increase the volume of our own uranium production. We also need to consistently move towards establishing our own (or jointly with Poland as an EU Member State) production of nuclear fuel, taking into account the constraints imposed on us by our international obligations. Qualitative development of the nuclear industry is not possible without the same development of a radioactive waste management system and spent nuclear fuel. Today, a number of projects are underway, such as the construction of a centralized spent fuel storage facility, which will allow Ukraine to escape from its dependency and significant financial losses related to spent fuel storage in Russia.

All of the above are possible if one condition is met. A very cautious and balanced approach must be applied to nuclear power when it comes to performing its social functions in electricity supply. Nuclear energy cannot be the sole and main load carrier. Tariff policy 
should be economically sound and allow for generating companies maintain the necessary level of security and develop. It is necessary to derive this type of generation from the discriminated (in comparison with other types of generation) situation both in terms of financial and economic indicators and in terms of loading existing capacity. The implementation of this set of measures will allow Ukraine to retain and strengthen the most powerful driver of the economy, which will not only have a favorable impact on the financial and economic and technological development of the country, but also stimulate the development of a number of related industries.

Security. There are two aspects to be distinguished here: operational and production.

The safety of operating nuclear power units has many components. One of the main is professional and independent regulation. Independent position of the nuclear regulator legally enshrined, its strengthening, expansion of the material and technical support base of the regulator will allow to put safety issues at the forefront and avoid situations in which tactical economic or political considerations may prevail over security. The independence of the nuclear regulator will also avoid conflicts of interest. It is very important at the state level to resist the temptation to manage the industry and regulate it manually. Nuclear power requires a systematic management approach and independent regulation.

The safety of the production of nuclear reactors, equipment and other components of nuclear technology are associated with high risks of information leakage and others, and therefore require special protection systems that domestic engineering companies are not able to provide at the current level. A possible solution is to organize cooperation on the basis of internationalpublic-private partnerships in order to diversify risks. The foreign partner provides the technologies, the SBU provides protection against the leakage of classified information, the domestic enterprises provide technical and technological support for the production of modern equipment.

Education and human resources. The request for training, as the policy of preserving existing human resources, including its reserve component, directly related to the following factors: the current economic and financial situation in the industry and the development prospects of the industry in terms of new capacities construction and commissioning. In the matter of training, it may make sense to focus educational methodological base. This will improve the quality of education and to create a healthy competition for educational places is "smearing a thin layer of "available resource. It is necessary to avoid the situation that exists now, when the fullness of the student in the relevant specialty is only about $30 \%$. Backed by powerful industry, our educational institutions, in particular the Dnipro state Univer- sity of chemistry and technology, in addition to implementing internal problems, would systematically expand the export capacity of the domestic higher education system in the field of nuclear energy. It is advisable to develop modular units for the provision of professional knowledge and experience as a product of industry, rather than passively observing how the knowledge and experience flowing out of the country with specialists.

For the development of nuclear-industrial complex, it is advisable to use an innovative approach. This approach is represented as a set of three interconnected units, namely:

- methodical and informational block involves the development of methods for the assessment of the development of the nuclear industrial complex to improve the validity of decisions on the formation conditions of its reorientation on the basis of innovation, and the collection and primary processing of information for its further use in the evaluation process of the development of nuclear-industrial complex;

- diagnostic and indicative unit provides for implementation through the established information database according to the developed method of identification of the development type of Ukrainian nuclear-industrial complex and determination of its level and the development of recommendations on formation of conditions for innovation-oriented nuclear-industrial complex development;

- assessment-procedure - involves the assessment factors as the basis to further define the strategic determinants of innovation-oriented development, which needs to be developed actions to build conditions for innovation-oriented nuclear-industrial complex development, and forecasting expected results, and implementation that must be accompanied by the permanent control on the basis of comparison of the obtained results with the predicted.

Conclusions. It is advisable to include in the general results of the implementation of the program of development of the nuclear-industrial complex the following: increase of competitiveness of the enterprises of key strategic industries: nuclear, mining, metallurgy, chemical and mechanical engineering; increase of innovativeness of production through development of scientific potential of the region, commercialization of scientific process; enterprise development based on the latest industrial waste processing technologies, including for the development of the region's infrastructure; manmade load on the environment; creating more attractive and diverse jobs; ensuring the stabilization of the social processes of the mining regions. It is necessary to increase the volume of uranium production, to increase its level of enrichment and at the same time to solve environmental issues regarding waste disposal. 


\section{Literature}

1. Якубовський М.М., Ляшенко В.І. Модернізація економіки промислових регіонів: спроба концептуалізації. Вісник економічної науки України. 2016. № 1 (30). С. 188-195. 2. Ляшенко В.І., Котов С.В. Україна XXI: неоіндустріальна держава або «крах проекту»?: монографія / НАН України, Ін-т економіки пром-сті; Полтавський ун-т економіки і торгівлі. Київ, 2015. 196 с. 3. Горбулін В. Мій шлях у задзеркалья. Не лише подорожні нотатки. Київ: Брайт Букс, 2019. 272 с. 4. Носовський А.В. Ядерна енергетика в контексті сталого розвитку. Ядерна та радіаційна безпека. 2010. Вип. 2(46). С. 62-65. 5. Литвинський Л.Л., Пуртов О.А. Розвиток ядерної енергетики в Україні. Необхідність, недоліки та переваги. URL: http://www.kinr. kiev.ua/NPAE_Kyiv2006/proc/Litvinsky.pdf (дата звернення: 17 жовтня 2018 р.). 6. Максимчук О.С. Пріоритетні напрями державного управління процесами розвитку ядерної енергетики та атомної промисловості в Україні. Публічне адміністрування: теорія та практика. 2013. Вип. 1. URL: http://nbuv.gov.ua/UJRN/ Patp_2013_1_16 (дата звернення: 17 жовтня 2018 р.). 7. Мохонько Г.А., Тарасенко К.В. Проектний підхід в управлінні інноваційним розвитком підприємств атомної енергетики. Економіка і суспільство. 2018. Вип. 16. С. 417-424. 8. Мітяєва Т.Л. Поняття галузі та передумови іï формування. Економічна стратегія $i$ перспективи розвитку сфери торгівлі та послуг. 2013. Вип. 2(1). С. 199-209. URL: http://nbuv.gov.ua/UJRN/ esprstp_2013_2\%281\%29_30 (дата звернення: 17 жовтня $201 \overline{8}$ р.). $\overline{9}$. Стратегія сталого розвитку України до 2030 року / Проект 2017. URL: http://www.ua.undp.org/ content/ukraine/uk/ home/library/sustainable-development -report/Sustainable-Dev-Strategy-for-Ukraine-by-2030. html (датазвернення: 16 жовтня 2018 р.). 10. Енергетична стратегія України на період до 2035 року «Безпека, енергоефективність, конкурентоспроможність»: Розпорядження Кабінету Міністрів України від 18 серпня 2017 р. № 605-p. URL: https://www.kmu. gov.ua/ua/ npas/250250456 (дата звернення: 16 жовтня 2018 р.). 11. Підприємства та компанії галузі / Офіційний сайт Міністерства енергетики та вугільної промисловості України. URL: http://mpe.kmu.gov.ua/minugol/ control/uk/publish/officialcategory?cat_id=24491606 (дата звернення: 17 жовтня 2018 р.). 12. Максимчук О.С. Напрямки забезпечення інноваційного розвитку підприємств сфери послуг. Удосконалення механізму інноваційного розвитку суб'єктів національної економіки України: колективна монографія / Т.В. Гринько, М.М. Кошевий, Г.Ю. Єлисєєва та ін.; за наук. ред. д.е.н., проф. О.К. Слисєєвої. Київ: Центр учбової літератури, 2013. С. 173-211. 13. Демьянюк В. АЕС найпотужніший драйвер економіки. Дзеркало тижня. 2019. №50. С. 13. 14. Маскалевич I. Уран проміжного поділу. Дзеркало тижня. 2018. №24-25. С. 9.

\section{References}

1. Yakubovsky M.M., Lyashenko V.I. (2016). Modernization of the economy of industrial regions: an attempt to conceptualize. Bulletin of Economic Science of Ukraine, No. 1 (30), pp. 188-195 [in Ukrainian].

2. Lyashenko V.I., Kotov E.V. (2015). Ukraine XXI: Neo-industrial state or project collapse? Kyiv, Institute of Industrial Economics NAS of Ukraine; Poltava University of Economics and Trade. 196 p. [in Ukrainian].

3. Gorbulin V. (2019). My way into the mirror. Not just travel notes. Kyiv, Bright Bucks [in Ukrainian].

4. Nosovsky A.V. (2010). Nuclear energy in the context of sustainable development. Nuclear and radiation safety, Vol. 2 (46), pp. 62-65 [in Ukrainian].

5. Litvinsky L.L., Purtov O.A. Development of nuclear energy in Ukraine. Necessity, disadvantages and advantages. Retrieved from http://www.kinr.kiev.ua/NPAE Kyiv2006/proc/Litvinsky.pdf (date of issue: October 17, 2018) [in Ukrainian].

6. Maksymchuk O.S. (2013). Priority Areas of Public Administration for the Processes of Nuclear Energy and Nuclear Industry Development in Ukraine. Public administration: theory and practice, 1. Retrieved from http://nbuv.gov.ua/UJRN/ Patp_2013_1_16 (date of issue: October 17, 2018) [in Ukrainian].

7. Mokhonko G.A., Tarasenko K.V. (2018). Project approach in the management of innovative development of nuclear power enterprises. Economy and society, Issue 16, pp. 417-424 [in Ukrainian].

8. Mityaeva T.L. (2013). The concept of the industry and the prerequisites for its formation. Economic strategy and prospects for development of trade and services, Issue 2 (1), pp. 199-209. Retrieved from http://nbuv.gov.ua/ UJRN/esprstp_2013_2\%281\%29_30 (due date: October 17, 2018) [in Ukrainian].

9. Sustainable Development Strategy of Ukraine to 2030 / Project 2017. Retrieved from http://www.ua. undp.org/ content/ukraine/uk/home/library/sustainable-development-report/Sustainable-Dev-Strategy-for-Ukraineby-2030.html (due date: October 16, 2018) [in Ukrainian].

10. Energy Strategy of Ukraine for the Period up to 2035 "Security, Energy Efficiency, Competitiveness": Order of the Cabinet of Ministers of Ukraine dated August 18, 2017 № 605-p. Retrieved from https://www.kmu.gov.ua/ ua/ npas/250250456 (due date: October 16, 2018) [in Ukrainian].

11. Enterprises so companies of the industry / Official site of the Ministry of Energy and Coal Industry of Ukraine. Retrieved from http://mpe.kmu.gov.ua/minugol/ control/uk/publish/officialcategory?cat_id=24491606 (due date: October 17, 2018) [in Ukrainian].

12. Maksymchuk O.S. (2013). Directions of providing innovative development of service companies. Improving the mechanism of innovative development of the subjects of the national economy of Ukraine: a collective monograph / TV. Grinko, M.M. Koshev, G.Yu. Yeliseyeva and others; for research Doctor of Economics, prof. O.K. Yeliseyeva. Kyiv, Center for Educational Literature (pp. 173211) [in Ukrainian].

13. Demianyuk V. (2019). NPP - the most powerful driver of the economy. Mirror of the Week, No. 50, p. 13 [in Ukrainian]. 
14. Maskalevich I. (2018). Uranium of the intermediate division. Mirror of the week, №24-25, p. 9 [in Ukrainian].

Ляшенко В. І., Шевченко В. Г., Осадча Н. В., Коломійцев О. А., Котко О. К. Тенденції та перспективи розвитку атомно-промислового комплексу України

У статті проаналізовано тренди розвитку атомнопромислового комплексу. Серед основних проблем розвитку атомно-промислового комплексу визначені недосконалість законодавчої бази, відсутність інвестицій. Необхідна кількість, збагаченого урану в ядерному паливі закуповується Україною тільки в РФ. Росія постачає відвал урану-235 після збагачення не менше $0,3 \%$.

Обгрунтовано необхідність розроблення послідовності етапів інноваційно-орієнтованого розвитку атомно-промислового комплексу Україні на основі стратегічних детермінант. Безпосередньо атомно-промисловий комплекс, який $є$ провідною ланкою ядерноенергетичного комплексу України, можна вважати комплексною галуззю національної економіки, що включає: уранове виробництво, що створює основу для задоволення потреби атомних електростанцій у природному урані на середньо- та довгострокову перспективу; цирконієве виробництво, яке передбачає налагодження випуску цирконію, що є основним конструкційним матеріалом для виготовлення ядерного палива 3 огляду на його унікальні фізичні властивості слабкої взаємодії 3 нейтронним потоком в активній зоні реактора; виробництво іонообмінних матеріалів та забезпечення ними в повному обсязі уранове виробництво України; виробництво тепловидільних збірок та комплектувальних виробів як невід'ємної ланки створення власного ядерно-паливного циклу; наукове, проектне та інформаційне супроводження проведення науководослідних робіт. В Україні відсутній профільний інститут, який би займався координацією науково-дослідних питань щодо розвитку атомно-промислового комплексу.

Внесок атомно-промислового комплексу України у створення валового внутрішнього продукту не $є$ значним, але його роль важлива щодо забезпечення економічної безпеки та досягнення енергетичної незалежності країни. Основні засади розвитку атомно-промислового комплексу доцільно відобразити у державній Програмі розвитку галузі та в Стратегії розвитку регіону. Для розвитку атомно-промислового комплексу доцільно використовувати інноваційний підхід. Даний підхід представлено як сукупність трьох взаємопов'язаних блоків, а саме: методико-інформаційний; діагностично-орієнтувальний; оціночно-процесуальний.

Обгрунтовано необхідність збільшення обсягу видобутку урану, рівня його збагачення та одночасно рішень екологічних питань щодо утилізації відходів

Ключові слова: атомно-промисловий комплекс, промисловість, енергетика, енергетична безпека.
Liashenko V., Shevchenko V., Osadcha N., Kolomiytsev O., Kotko O. Tendencies and Prospects of the Ukrainian Nuclear Industrial Complex Development

The article analyzes development trends of the nuclear-industrial complex. Among the main problems of development of nuclear-industrial complex determined inadequate legal framework, lack of investment. the required amount of enriched uranium in nuclear fuel purchased by Ukraine only in the Russian Federation. Russia supplies the stockpile of uranium-235 after enrichment not less than $0.3 \%$.

The necessity of development sequence the stages of the innovation-oriented development of nuclear-industrial complex of Ukraine on the basis of strategic determinants. Directly the nuclear-industrial complex, which is the leading element of the nuclear energy complex of Ukraine can be considered a complex sector of the national economy that includes production of uranium, which forms the basis to meet the needs of nuclear power plants in natural uranium in the medium and long term; Zirconia production, which includes the establishment of the production of zirconium, which is the main structural material for the fabrication of nuclear fuel, given its unique physical properties of the weak interaction with neutron flux in the reactor core; manufacture of ion-exchange materials and to ensure the full production of uranium of Ukraine; production of fuel assemblies and components as a key link in the creation of our own nuclear-fuel cycle; research, design and information support of scientific research. In Ukraine there is no specialized institution that would deal with the coordination of the research questions regarding the development of nuclear-industrial complex.

The contribution of the nuclear-industrial complex of Ukraine in the creation of gross domestic product is not significant, but its role is important in ensuring economic security and achieving energy independence. The basic principles for the development of nuclear-industrial complex should be reflected in the state Program of development of the industry and development strategy of the region. For the development of nuclear-industrial complex, it is advisable to use an innovative approach. This approach is represented as a set of three interconnected units, namely: methodical-information unit; diagnostic-estimated; estimating procedure.

Reasonably necessary to increase the volume of uranium production, increase the level of its enrichment and at the same time to solve environmental issues on waste management

Keywords: nuclear-industrial complex, industry, energy sector, energy security.

Ляшенко В. И., Шевченко В. Г., Осадчая Н. В., Коломийцев О. А., Котко О. К. Тенденции и перспективы развития атомно-промышленного комплекса Украины

В статье проанализированы тенденции развития атомно-промышленного комплекса. Основными проблемами развития атомно-промышленного комплекса являются несовершенство законодательной базы, от- 
сутствие инвестиций. Необходимое количество обогащенного урана в ядерном топливе закупается Украиной только в РФ. Россия поставляет отвал урана-235 после обогащения до $0,3 \%$. В статье обоснована необходимость разработки последовательности этапов инновационно-ориентированного развития атомно-промышленного комплекса Украины на основе стратегических детерминант.

Непосредственно атомно-промышленный комплекс, который является ведущим звеном ядерно-энергетического комплекса Украины, можно считать комплексной отраслью национальной экономики, которая включает: урановое производство, создающее основу для удовлетворения потребности атомных электростанций в природном уране на средне- и долгосрочную перспективу; циркониевое производство, которое предусматривает налаживание выпуска циркония, что является основным конструкционным материалом для изготовления ядерного топлива, учитывая его уникальные физические свойства слабого взаимодействия с нейтронным потоком в активной зоне реактора; производство ионообменных материалов и обеспечение ими в полном объеме урановое производство Украины; производство тепловыделяющих сборок и комплектующих изделий как неотъемлемого звена создания собственного ядерно-топливного цикла; научное, проект- ное и информационное сопровождение, проведение научно-исследовательских работ. В Украине отсутствует профильный институт, который бы занимался координацией научно-исследовательских работ по развитию атомно-промышленного комплекса.

Значение и вес атомно-промышленного комплекса Украины в создании валового внутреннего продукта не является значительным, но его роль важна по обеспечению экономической безопасности и достижению энергетической независимости страны. Основные принципы развития атомно-промышленного комплекса целесообразно отразить в государственной Программе развития отрасли и Стратегии развития региона. Для развития атомно-промышленного комплекса целесообразно использовать инновационный подход. Данный подход представлен как совокупность трех взаимосвязанных блоков, а именно: методико-информационный; диагностико-ориентировочный; оценочно-процессуальный.

Обоснована необходимость увеличения объемов добычи урана, уровня его обогащения и одновременно решений экологических вопросов по утилизации отходов

Ключевые слова: атомно-промышленный комплекс, промышленность, энергетика, энергетическая безопасность.

Received by the editors: 16.12 .2019 and final form 19.12.2019 